\title{
SY Term Type
}

National Cancer Institute

\section{Source}

National Cancer Institute. SY Term Type. NCI Thesaurus. Code C45780.

The $\mathrm{NCl}$ term type designation for a synonym. 